\title{
SYRIAN CRISIS, MIGRATION, WOMEN AND VIOLENCE FROM PERSPECTIVE OF FEMINIST SECURITY STUDIES ${ }^{1}$
}

\author{
Kafkas University \\ Economics and Administrative \\ Sciences Faculty \\ KAUJEASF \\ Article Submission Date: 01.06.2021 \\ Accepted Date: 26.08.2021
}

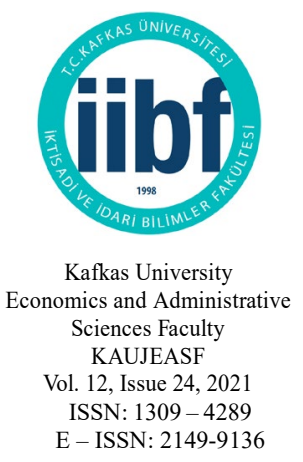

Zuhal KARAKOÇ DORA

PhD, Deputy President

Turkish Grand National Assembly

Presidency of Strategy

Development,

Ankara, Turkey

zuhal.dora@yahoo.com

ORCID ID: 0000-0002-3954-2208

\begin{abstract}
I In the discipline of International Relations, migration is primarily handled as a matter of security. This perception of security is come into view as a result of politics determined at different levels in the manner of individual, society and the state. However; taken the masculine construction of the discipline of International Relations into consideration, it becomes clear that the phenomenon of "violence", of which major sufferers are women, is to be tackled with a completely new perspective. Preventing the violence before, while and after the migration is of vital importance in procuring the security of the guest and the host communities and their integration simultaneously. In this article, by referring to the change of security studies and the expanded security agenda, the concepts of migration and violence are examined from a woman-oriented perspective within context of the Syrian crisis and under the framework of the feminist security approach.
\end{abstract}

Keywords: Feminist security studies, migration and violence, Syrian crisis.

Jel codes: F22, K33, I38

Scope: International Relations and Political Science

Type: Review

DOI: 10.36543/kauiibfd.2021.049

Cite this Paper: Karakoç Dora, Z. (2021). Syrian crisis, migration, women and violence from perspective of feminist security studies. KAUJEASF, 12(24), 1218-1236.

\footnotetext{
${ }^{1}$ Compliance with the ethical rules of the relevant study has been declared.
} 


\section{FEMINIST GÜVENLİK ÇALIŞMALARI BAĞLAMINDA SURIYYE KRIZİ, GÖÇ, KADIN ve ŞIDDET}

\section{ÖZ} alınmaktadır. Bu güvenlik anlayışı; bireyi, toplumu ve devleti ele alacak şekilde farklı seviyelerde belirlenen politikaların bir sonucu olarak karşımıza çıkmaktadır. Ancak uluslararası ilişkiler disiplininin eril yapısı göz önünde bulundurulduğunda, kadınların birincil mağdur konumunda bulundukları "şiddet" olaylarına yaklaşımın yeni bir perspektifle ele alınması gerektiği gerçeğiyle karşılaşılmaktadır. Göç öncesinde, esnasinda ve sonrasında ortaya çıkabilecek şiddet olaylarının önüne geçilmesinin; göç sürecinde misafir ve ev sahibi toplumların güvenliğinin ve uyumunun eşzamanlı sağlanabilmesine imkan tanımak noktasında ilk sıralarda yer aldığı bir gerçektir. $\mathrm{Bu}$ makalede güvenlik çalışmalarının geçirdiği değişim ve genişletilmiş güvenlik gündemine değinilerek feminist güvenlik yaklaşımı çerçevesinde ve Suriye krizi bağlamında kadın odaklı bakış açısıyla göç ve şiddet kavramları irdelenmektedir.

Anahtar Kelimeler: Feminist güvenlik çalışmaları, göç ve şiddet, Suriye krizi.

JEL Kodu: F22, K33, I38

Alan: Uluslararası İlişkiler ve Siyaset Bilimi Türü: Derleme 


\section{INTRODUCTION}

The main actor in international relations studies until the end of the Cold War was the "state" and the dominant theory was "realism". Considered from pre-modern times, it is witnessed that this reality differs in very few insignificant examples. However, in the last periods of the Cold War, classical and traditional approaches in the field of international relations have started to be criticized with the claim that current approaches do not prevent wars or reduce the negative outcomes of wars. During the last period of the Cold War new approaches have emerged based on the idea that the security area, which was generally defined as a sub-field of Strategic Studies, should express not only the military field but also other areas and counting on the fact that the threat perception started to transform and diversify. One of them is the Feminist Security Studies, which adopt a security approach that basically takes the "individual" and in particular the "woman" into centre.

Feminist Security Studies highlights the lack of a female perspective in a male-dominated discipline and focused on the violence faced by women in many areas from social life to business life, from war to politics, and explores ways to eliminate them. In the post-Cold War era, the period when security threats can take shape in infinite combinations, this need has been further strengthened by statistics showing that women are most affected by conflicts and resulting immigration.

As it is known, immigration is one of the new security threats created by the post-Cold War era and is still up-to-date and important today. While immigration, as the dominant phenomenon of human history and one of the most rooted nature inherited by human being, aims to improve the conditions if it is "voluntary" while it refers to uncertainity and clinging to the priority of survival when it is "forced". When dealing with the issue of immigration, which has different types and levels of difficulties for both the migrants and the hosting communities, the feminist approach focuses on women. Although they do not usually play an active role in the effects that cause migration and they are not the ones who mostly decide to migrate; in terms of undertaking heavy responsibilities, difficulties to be faced and threats to be exposed, the role of woman in the migration process and her gender-based obligations and victimizations are far beyond predictions and statistics. It is now an internationally accepted reality that women and, as a natural consequence, children are most affected by forced migration, which is a psychosocial crisis.

The civil war in Syria has led to the most devastating refugee crisis of the 
last two decades (UNHCR, 2015) and has become one of the most important agenda items of the world, especially in Turkey. "Migration", one of the most traumatic outcomes of humanitarian crises and conflict environments, is deployed in the international system as a political discourse/tool/power /bargaining element; has been frequently discussed both in political and economic terms, and its causes and consequences have been the subject of numerous studies.

However, according to the proponents of the feminist approach, it is difficult to claim that the "process" and "management" parts, which might minimize the long-term damages of immigration, get the appropriate requital they deserve from decision-makers. In this study, in order to overcome the Syrian Crisis with the least damage in terms of both the Syrian guest community and Turkish society in the long run; it is explained what migration and security policies might include in the context of feminist security studies. The idea that women who have more negative conditions in respect of being affected by the outcomes of migration process are to be the taken at focal point of this process with a two-sided fiction; not only as an object of the policy element but also as policy/decision makers.

Within this framework, Feminist Security Studies defend that women oriented approach should not be excluded while determining the security strategies of Turkey, who has been hosting more than 4 million Syrian refugees by applying the Open Door Policy for the victims of the civil war in Syria since 2011. From this point of view, it focuses on the evaluation of current migration policies and determination of areas open to improvement. In this article, based on the preliminary argument that "no theory alone can fill a gap", it is emphasized that all theories should be used in a blend in accordance with international law towards war victims and at the same time in contribution to both national interests and international peace while setting policies.

\section{TRANSFORMATION OF SECURITY STUDIES}

According to Baldwin's study, which includes seven elements of security, the answers given to the questions of "security for who and for what values, against which threats, with what tools, at what cost, how long and to what extent?" give us the definition of security (Baldwin, 1997: 5). On the other hand, the works that define the concept of security mostly deal with two elements of these: first one is security subjects, answering the question of security for whom and second is the security threats, answering the question of security against what (Aydın et al. , 2015: 14). Security studies largely remained under the guise and shadow of realism until the end of the Cold War, and threats from the military arena due to wars and conflicts that swept the world have always been the most 
important agenda which caused the security subject to be limited with the state and the security threat with military ones. However, with the crash of the Soviet Union and the end of the bipolar order, a process of change started in the International Relations discipline and this change brought about three important results in terms of the security studies sub-discipline: the transformation of the security agenda, the questioning of security studies and the emergence of new approaches (Aydin et al., 2015, 103).

With the end of the Cold War, the expanded security agenda gained legitimacy and prestige and a transformation process started under the leadership of Barry Buzan and Richard Ullman, who opposed the established tradition during the period when the military point of view was dominant (Wyn-Jones, 1996: 206). This transformation, which started in the field of security studies, criticized the narrow perspective of the traditionalist perspective in many respects, and it was emphasized that the concept of security was insufficient to cover a single field. According to Buzan security was not limited to the military field and could be categorized in five different sectors; military, political, economic, social and environmental security (Buzan, 1991, 19-20). Starting off from the fact that the concept of security is not a clear and precise concept that can be accepted by everyone, Buzan argues that, in the modern period, security threats vary in a way that can include or exclude different sectors according to the specific location and conditions of each country, and this volatility and inconsistency, which makes security impossible to fit into a common pattern,very much suits policy makers (Buzan, 1991: 1-21). Because in the global order, there are other threats of degradation that can go far beyond the threat of war, and these threats, which can range from natural disasters to economic dependence, from mass migration to political instability, from human rights violations to inequality; correspond to different levels of risk for each country which well explains the order of priorities and changes in each country's policies.

According to Ullman, one of the advocates of the extended security approach, security threats are threats that reduce the quality of life of the citizens of a country or narrow the policy preferences of private, non-state actors (individual, group, company) and governments in a country (Ullman, 1983: 134135). The new problems that emerged on a global scale were now directly affecting not only states and their governments, but also non-state actors, especially societies and individuals. But politicians did not find it rewarding (vote-bringing) to raise non-military threats on the agenda and analysts did not find it intellectually easy and practical; because it was very difficult to compare one type of threat with another and to measure the relative contribution of the 
various ways governments could use the resources at their disposal to national security (Ullman, 1983: 129). For this reason, it was not possible until the end of the Cold War to force the traditional walls of realism, which made military threats the sole focus of the field and was easy to measure and politicize.

The inability of traditional concepts and theories to predict and explain transformations in global politics and the failure of realist theory and its derivatives to analyze the actors, causes and consequences of the radical change process since the late 1980s, led to the emergence of new theories in the international relations discipline (Demirtaş, 2019: 1). A fast and concrete wind of change has blown in security studies and this new era has been named as "New Security Studies" with the adoption of new approaches that question the classical security understanding and argue that the security agenda should be expanded. Unlike traditional realists who take the state as the main subject of security, the individual is more prominent in new security studies. However, the fact that new security studies point to the politicism of security and propose to focus on human security as a new policy does not mean that state security has been put in the background; on the contrary, the prerequisite for the security of citizens corresponds to the security of the state in a way because if the state is safe, the citizens are also safe (Bilgin, 2010: 77).

\section{FEMINIST SECURITY APPROACH}

Security Studies were born in the 1940s as Strategic Studies and after being under the influence of a realist perspective for a long time, it has become a comprehensive discipline that hosts many security theories, including Realist Security Studies (Aydın et al., 2015: 103). With the transformation it has undergone since the $80 \mathrm{~s}$, it has begun to incorporate different theories, and while some theories have been put forward to replace another one, some have appeared as complementaries to others. Considering all the stages of security studies the picture ahead is as follows: the needs of the changing world are not stable, and new approaches to compensate for the disruptions brought about by new threats inevitably and naturally follow these changes.

The emergence and development of the feminist approach in international relations is based on two basic principles: the first is the fact that the majority of political and military decision-makers and academicians working in this discipline are men, and second is the fact that the analyzes and practices in foreign policy are explained with masculine concepts and are made by emphasizing male-specific behavioral patterns (Demirtaş, 2019: 1). In the feminist approach, it is argued that the state-centered understanding of security cannot appropriately analyze the gender-specific security problems faced by 
women and cannot bring satisfactory solutions to them; because, according to feminists, the subject of security is the individual and the hegemonic masculinity in the system leads to more militarist security policies (Aydın et al. 2015: 109). According to this approach, the subject of which is the individual; the fact that all individuals are not represented in proportion to their gender in the process of making international relations analyzes and practices, as well as political and military decisions taken on the way to these practices, causes an important gap and challenges. Considering that women, who make up roughly half of the individuals in the society, are not represented in male hegemony in proportion to their numbers; it is thought that both the discipline of international relations and the political sphere cover as much as a single eye can see, not the area that can be seen by two eyes. This incomplete perspective might lead to significant political mistakes and traumas that cannot be repaired in the long run.

The feminist approach argues that there is a strong link between the individual life -especially women's life- and the security phenomenon in the field of security and rejects the national security-based and masculine state-oriented understanding by stating that the realist approach incorporates structural violence (Blanchard, 2003: 1290-1296). In addition to the direct violence experienced in wars and attacks resulting with deaths and pains; there is also structural violence arising from situations such as hunger or illness, or economic, cultural, social and/or legal discrimination, and the victims of this violence are mostly women. (Terriff, 1999: 46-50). In Feminist Security Studies, the security problems of women who are subjected to structural and physical violence and even marginalized to the point of "silence" in the society are addressed and within this framework and the problems that women experience are included in the concept of security by drawing attention to the fact that the majority of the immigrant population in the world consists of women and children, rape is still a means of war, violence against women in society (such as honor killings, domestic violence) is spreading and income level of working women is relatevely low (Aydin et al., 2015: 15).

The feminist approach is an important part of the expanded new security understanding in this context, and it answers the question of "whose security?" as "the security of the individual and society". Because, according to feminist approach, if the individual is not safe then the society is not safe, and if the society is not safe, the security of the state should be questioned. They approach the question of "security provided by whom?" at a distance due to dominant patriarchal structure. While rational theories say that the state will provide security, according to gender studies, it should be questioned whether the state 
does this in a way that ensures equality for both sexes as because both civilian and military decision makers are mostly male and the use of masculine concepts while deciding on policies and the implementation of masculine tools and policies in practice make this area controversial (Demirtaş, 2019: 2-3). However, the feminist approach does not reduce the solution of this problem of masculinity in international relations to the solution of "women with adequate representation" in this field. At this stage, it deals with the concept of gender because gender refers to the attitudes imposed by society on individuals and the attitudes that society expects from the individual by identifying with sexes. And according to the feminist approach, gender and the masculine structure, which makes itself clear on the basis of realism in international relations, is a mechanism that constantly feeds each other. For this reason, the update of the masculine perspective by including all members of the society equally will not be possible with "equal representation of women" solely, but with an additional holistic perspective and a comprehensive solution of gender issues.

\section{MIGRATION, SECURITY AND WOMEN IN THE EXAMPLE OF THE SYRIAN CRISIS}

According to Buzan, who is one of the representatives of the expanded security understanding and introduced the concept of societal security threat for the first time, societal security is the sustainability of language, culture, religion, national identity and traditional features (Buzan, 1991: 122-123). Considering the issue of "immigration" from this perspective, it is known that international forced migration can cause a security threat and crisis for host countries as well as being a humanitarian crisis. The phenomenon of international migration emerges as a reality in which the social stability, demographic security, cultural identity, social security system and welfare state philosophy and internal security are affected on the basis of the national security of states (Şener, 2017: 2).

The perception of security now goes beyond the state-based understanding built on eliminating and protecting communities living within certain boundaries, threats and risks from aggressive societies; it evolves towards an understanding that emphasizes the importance of individuals feeling safe against different economic, political and physical threats (Özdemir et al., 2018: 125). In this respect, individuals can consider migration as a way out to establish their own security. International migration starts from individual-based security concerns, but can reach to a point where it might threaten the hosting society and the state over time. These threats begin in the country of origin of migration and continue for both communities in the target or transit country. Feminist approach places women at the very centre of "migration", which poses different and 
varying levels of difficulties for both the migrant and the receiving party. As mentioned above, although they do not usually play an active role in the effects that cause migration and they are not the ones who mostly decide to migrate; in terms of undertaking heavy responsibilities, difficulties to be faced and threats to be exposed, the role of woman in the migration process and her gender-based obligations and victimizations are far beyond predictions and statistics.

Forcedly displaced women are subjected to sexual and gender-based (physical and structural) violence - beyond general security concerns - owing to inadequacy of secure climate over the course of migration (Özdemir et al., 2018: 126). In addition, various psychosocial pressures faced by women, different cultural expectations and challenges such as women's lack of education or language competence, reinforce the disadvantageous position of migrant women in the hosting society even after migration. (Şeker and Uçan, 2016: 210). Women, after migration, become estrangered to many things as a consequence of social isolation, seclusion, language handicaps and cultural divergence (Tuzcu et al. , 2015: 64) and stumbles upon structural barriers that facilitate isolation from society. For this reason, it is of great importance to evaluate the concept of gender in international security studies in terms of investigating the threat perception of refugee women during and after forced migration, and preventing/ eliminating the negative effects of migration process (Özdemir et al. , 2018: 127). Because the failure to ensure the security of the individual may endanger the security of the society and the failure to ensure the security of the society can endanger the further security of the state.

Although women of the immigrant society come to mind first when it comes to migration and women, women living in host countries are also an important part of this process. As a matter of fact, it does not seem easy for them to accept the new situation as well. Because, while trying to construct the future of their families and children, they suddenly face the fact of sharing the ancestral savings of their own lands (shrinkage of Gross National Income, shrinkage of employment, decrease in the quality of education and health services due to sudden population increase, decrease in purchasing power as a result of increasing prices due to increase in demand, security problems brought about by irregular settlement etc.) and therefore the motive to protect them from the difficulties aroused from this new situation is activated. For this reason, in the new picture created by "migration, ensuring "harmony" in order to protect the social fabric and preventing social conflicts are mostly related to how "women" are positioned in this process.

Addressing the issue from this perspective and preventing violence 
before it occurs is important not only for the refugee communities, but also for the security of the host community. Sudden and intense mass migrations increase the vulnerability and sensitivity of the host society, negatively change the perception towards refugees and increase reactivity. Such environments where the fragility of both societies is at a high level triggers social conflicts. Therefore, the "process" as well as "duration" of migration should be addressed before social sensitivities reach destructive dimensions. In this context, feminist approach considers security from an individual-oriented view and advocates that women in the migration process should be positioned with a gender-focused perspective.

According to the data of the United Nations High Commissioner for Refugees, $53.2 \%$ of the Syrians in Turkey are women (UNHCR, 2019). From this perspective, in Turkey, who hosts a Syrian population of approximately 4 million, the issue of immigration is to be considered as a multi-faceted reality with a predominant psychosocial side and the policies are to be determined on the axis of "harmony". Here, the element that should not be ignored is that harmony does not mean an eventual "stay", it refers that this period and process need to be overcome with the least damage for both communities, regardless of the time it takes until Syrians return to their homeland, and that it covers both the guest community and the host community. It is a fact that in countries with large numbers of asylum seekers, integration policies cause anxiety. Because, cohesion policies mean not only acceptance of permanence, but also encouragement (Erdoğan, 2016). But cohesion policies are also an important security measure that closes the way to social chaos and constitutes an invisible order between those who have been forced to leave their country due to internal turmoil and those who have increased vulnerability and vulnerability. The important point to note here is that the adaptation of the current Syrian refugees is to be designed and managed in accordance with the safe return policy. In order to manage the migration and the process correctly and to prevent possible social damage, the focus of these policies should be "woman" as a figure whose power of discourse has been increased.

Feminist security approach draws attention to physical violence while supporting these policies in order to prevent the structural violence that women are subjected to due to their gender. Physical violence that women face during wars and internal conflicts which lead to forced migration, has been accepted internationally as a result of the shocking experiences and the findings of many researches, and has been the subject of the United Nations Security Council's (UNSC) Resolution 1325. According to the aforementioned decision of the UNSC, a gender perspective should be brought to peace operations, the 
international legal system regarding the protection of the rights of women and girls in armed conflicts should be specifically put into effect, and measures to include women in all implementation mechanisms of peace agreements should be taken. Emphasizing the importance of including women and girls in preconflict, conflict and post-conflict resolution processes, this Decision also recommends that states parties prepare and implement a national action plan on this issue (UN Security Council Resolution 1325, 2000).

"One of the most important features of the 1325 resolution, together with the complementary resolutions that supported this decision and passed after 1325, is that the women's civil society forced the United Nations to recognize their role in the field of peace and security. The decision consists of four main pillars: 'prevention' (elimination of sexual and gender-based violence against women), 'participation' (increasing decision making roles of women in every area), 'protection' (ensuring the rights of women and children) and "relaxation and recovery' (ensuring and increasing gender euality) (UNSC, 1325)."

According to Ann Tickner, one of the leading names of the feminist approach in the field of international relations, although it is said that young men have embarked on the war to protect women and children, when looked at the death rate at the end of the war, we see that the number of women is much more than men (Tickner, 1997: 627). The statistics that support the fact that the victims of war are predominantly women and children are not just about mortality. Utilization of rape as a means of warfare in conflict situations also includes another dimension of this violence. As a matter of fact, the inclusion of sexual and gender-based violence against women within the scope of war crimes for the first time with the UN resolution 1325 on October 31, 2000 is based on the events that took place in the 1990s (UN Security Council Resolution 1325, 2000). During the civil war in the Former Yugoslavia in the early 1990s, approximately 20,000 rapes were committed by the Serbs against Bosnian women, and in the same period, during the genocide in Rwanda, an estimated 250,000 to 500,000 rapes were committed against Tutsi women by the Hutus (WHO, 2019). But there are much older examples of rape being used as a part and / or instrument of war. During World War II, in Japan, over 200,000 non-Japanese women were held hostage in rape camps to be used in the service of Japanese soldiers, and all women in these camps were systematically raped during the war (Beltz, 2008: 171-172). Again, in line with the testimonies given by the witnesses in the cases opened after 
the war, the French military unit under the command of General Eisenhower during World War II committed rape against German women in only the city of Stuttgart was over 2000, which corresponds to a number more than the total number of rapes committed by German soldiers against French women for 4 years (Beltz, 2008: 175).

The fact that the UNSC Resolution was taken as a result of the tragic consequences of war and conflicts, that is, after hundreds of thousands of women became victims, is a subject of discussion. Because, without considering the political and social background that creates and sustains violence, the way to seek solutions through the outcomes of violence is simply an acute intervention and does not represent a long-term and stable solution. As it is, the absence of considerable decreases in numbers even after the UNSC Resolutions proves this situation. According to the research carried out by the UN and non-governmental organizations in 2004 , it was revealed that $60 \%$ to $70 \%$ of the civilian population in Liberia were exposed to rape or other forms of sexual violence, and the majority of the victims were women and children (Beltz, 2008: 181). Again, according to UN reports, over 40,000 women and children have been raped in Uganda since 1999 (Beltz, 2008: 186).

When we look at the data of the civil war in Syria, we come across a startling picture. Even before the conflict Syria was ranking at the very bottom of the world ranks in means of Gender Inequality Index (133) and Global Gender Gap Index (142) which includes child marriage, domestic violence, physical and/or sexual violence, deficiency of access to justice and equal opportunities in education, empowerment (rate of participation in decision making processes) and rates of employment (UN Women, 2021). But with the picture started to worsen with the effect of the civil war that broke out in 2011. Women constitute the majority of displaced people in Syria conflict though the precise numbers are not noted and according to UNFPA (The United Nations Population Fund) about $78 \%$ of them are women and children (UNFPA, 2014).

The harsh conditions of the war bring along more and more difficult and wearing conditions for women in such kind of states where gender equality is already low. They easily turn into victims because of both inability to make their own decisions and being imprisoned in a more passive situation. Syrian Network for Human Rights (SNHR) draws the attentions to the fact that women and girls in Syria are exposed to various forms of violations like consensual murders, imperious arrests, torture, executings, compelled disappearings, sexual violence, forcedly displacements, besieging battles, and prohibition of healthcare and basic 
utilities (SNHR, 2019). SNHR monitored that Syrian women and girls have become straight and intentional targets of all parties to conflict, primarily the government forces, and the perpetrators conduct any kind of brutal violence against women (SNHR, 2019). According to reports released by the observers of NGOs, military forces of the government and armed gangs have been committing rape and sexual violence as war instruments all along the conflict and in 2013, the UN tried to relieve 38,000 sufferers of sexual violence, and many of the sufferers looked for help as refugees in neighboring countries (HRC, 2016). Between 2011 and 2019 SNHR reported 28.076 deaths of women and girls, with the government forces being responsible for almost $78 \%$ of these extrajudicial killings, a total of 90 reportedly died due to torture and at least 10.363 women and girls were still detained or forcibly disappeared at the hands of the main parties of the conflict (SNHR, 2019). The UN Independent International Commission of Inquiry on the Syrian Arab Republic (COI) affirmed that military forces of the government in Syria and the army under the control of the government (Shabbiha) conducted sexual violence as a war tool during home searches and at control points; besides, human rights authorities reported countless cases of rape, such as gang rape, and other types of sexual violence in those places and in custody, conducted by security forces against women and girls they assume are related to being opponents and depending on a report, security forces of the government seized young women and girls at control points, and after some while returned them to their families, deliberately indicating them as rape victims for the purpose of exposing them to embarrasment and repudiation (HRC, 2016). UN Human Rights Council reports that sexual violence committed by the government forces has regularly been connected to other types of violence and killings: "women and girls who were raped often witnessed the killing of male relatives, and in several instances eyewitnesses recalled women and girls being killed after being raped; besides, if they try to resist sexual assault they are severely beaten or killed" (UN Human Rights Council, 2018: 7). Yet, the violence women exposed to does not end there, violence mostly brings further violence. As well known survivors of sexual violence are not able to get support from their own communities, they are often perceived as dirty and unworthy as they are accused of being responsible for the loss of their families' honour (Abu Assab, 2017: 24). According to UNFPA reports many of the honour murder incidents are affiliated to sexual violence but not necessarily rape and as for the report honour murders might be a response to bullying or abuse, to presumed sexual violence during seize and even to an independent decision of a girl cregarding whom and when to get married (UNFPA, 2019). The UNFPA reported further profiles or levels of social status for which the risk of sexual and gender-based 
violence against women and girls in Syria was more severe and expanded while pointing out that they have been bearing the greatest part of the outcomes of war and the humanitarian crisis (UNFPA, 2019).

The violence against women during Syrian conflict is not limited to those applied by the government forces. Syrian conflict opened a perfect path for terrorist organisations to turn the instability and lack of security at borders or checkpoints to an opportunity (Karakoç Dora, 2020: 514). These terrorist groups are mostly known to abuse women both by arming girls and using them in conflicts, and by perpetrating sexual violence against women and girls (even under the age of 9). ISIS is one of them who is responsible for kidnapping thousands of Yazidi women and girls and subjecting them to domestic and sexual slavery (Wyke, 2015). The ISIS conducts systematic sexual enslavement and forced marriage to appeal warriors and to prize fighters and ethnically minor women are purchased at "slave markets," and rape is so common that most are put on persistent birth control schemes (TIMEP, 2017).

Widowed, divorced, or alone women also records sexual assault from patrons, landholders, and/or others as almost 35\% of Syrian refugees live in female-headed households, and the incomes of these families are $15-32 \%$ lower than male-headed ones, which leaves women fragile to sexual abuse in return for payment (TIMEP, 2017). As can be well seen, the violence women face during Syrian crisis may vary from serial temporary marriage to forced/ child marriage, from rape to sexual assault, from requesting for sex in return for aid or border crossings to survival sex and can be seen anywhere from camps and shelters to markets or streets, from distribution points or check points to hospitals (UNFPA, 2019). The Women's International League for Peace and Freedom (WILPF) remarks in its 2016 report that the war in Syria has affected women severely and disproportionately, for instance by limiting their access to health care and adding further burdens to their already existing responsibilities (WILPF, 2016: 24). The use of explosive weapons obstructed their access to medical care, even in cases where pregnant women were at risk of losing their lives or their unborn children by making their access to emergency medical assistance impossible (WILPF, 2016: 16).

It is known that the extent of gender-based physical violence experienced in civil conflict and war environments is much more than reflected in the records and figures. Because gender pressure, the fear of being exposed to pressures such as exclusion from society, domestic punishments and humiliation force women 
to fear and avoid telling about the traumas they exposed to. Furthermore, the data collected is generally limited to the cases that non-governmental organizations or independent observers can reach and interview one-on-one. It should not be overlooked that in closed societies like Syria, it is generally difficult to reach the individual and the individual who is reached generally prefers to remain silent because she cannot predict what may happen to her later due to abovementioned reasons. Therefore, it is considered that the data presented correspond to a very small part of the actual figures. The intertwining of structural and physical violence in Syria explains the feminist approach's insistence on the necessity to handle the issue in a holistic way.The feminist approach aims to provide an understanding of the gravity of the real situation based on the current data and recommends taking measures to prevent long-term social, regional and global threats. It draws attention to the importance of women-oriented policies in conflict environments in order to prevent re-experiencing the past traumas that led to the UNSC Resolution 1325.

In addition to the dimension of ensuring the safety of women and girls during and after migration, the fact that violence against women is one of the reasons for migration should not be underestimated. One of the most important consequences of the violence that women are exposed to is the Syrian-origin migration movement, which affected the whole world and Europe, starting from the neighboring and regional countries. In 2019, it is indicated in World Bank reports that cases of domestic violence, rape (including marital rape), forced marriage to armed group fighters, trafficking, and sexual enslavement have all increased in scale and scope and the Worl Bank identified the fear of becoming a victim of sexual violence and its possible consequences as one of the leading causes of displacement in Syria (WB, 2019: 20). In other words, while forced displacement can be a cause of exposure to violence, it can also be a result. Therefore, in the case of the Syrian crisis, which has caused the biggest number of displacement in the world (EC, 2020) the situation becomes two-sided and requires additional attention.

\section{CONCLUSION}

Economic, social and political inequalities, which are among the elements of structural violence, create an insecure settings for individuals, hence structures that will create equal opportunities among individuals should be ensured for comprehensive security (Tickner, 2004: 45). Since international relations and security have a dominant masculine character, women are often marginalized in security studies (Enloe, 2014). Economic and political decisions taken by the masculine nationally and internationally strengthen the existing 
patriarchal structure and increase gender inequality (Peoples, Vaughan-Williams 2010).

When studies are overviewed it is seen that women are generally portrayed as vulnareble people, potential victims and in need of protection in both media representation and political discourse which shows women passive and reflects an understanding that they are away from being an individual. Feminist security approach, here, indicates that security studies should not be considered apart from the gender studies as they are the complimentary part of each. If gender based approach is omitted, then the process to overcome the obstacles turns into a problematic area.

It is possible to observe the outcomes of this problematic in the Syrian refugee crisis. The Syrian refugee issue, which is considered as an emergency and caused developing short-term policies, continues to be on the agenda with the same uncertainty in its eleventh year. Though it is primarily a security problem, the current uncertainty leads the situation to a burden both economically and socially. Sensitivities that arise for both parties (guest and host communities) carry risks that might threaten the security of the society and the state in the long run. Before these sensitivities reach to an irreparable level; it is of vital importance to determine measures to protect the right to life of women and girls who are victims of war and prevent them from being exposed to any kind of violence while on the one hand, pursuing a safe return policy. According to feminist security approach, this is only possible by increasing the active role and power of women in the decision-making mechanisms.

Increasing the power and voice of women in decision-making mechanisms means opening the doors to platforms where not only the effects of war are discussed, but also the effective ways to prevent war is discussed. In order to protect the social fabric, to reveal the political and social grounds that shape social causes and to produce permanent solutions; women should be placed at the very center of policies and decision-making mechanisms as policy makers. The phenomenon of migration should be reconsidered and well-analyzed in this respect, and in the process of determining both international peace-building policies and multi-component adaptation policies aimed at minimizing social trauma at the national scale, "women" should play their roles at the front stage as actors, not at the sidelines as victims.

\section{CONFLICT OF INTEREST}

There is no conflict of interest in this article. 


\section{FINANCIAL SUPPORT}

The author received no financial support fort he research, authorship, and/or publication of this article.

\section{AUTHOR CONTRIBUTIONS}

ZKD: Idea

ZKD: Design

ZKD: Resource collection and processing

ZKD: Analysis and interpretation

ZKD: Literature research

ZKD: Author

ZKD: Critical analysing

\section{STATEMENT OF ETHICS COMMITTEE AND INTELLECTUAL PROPERTY COPYRIGHTS}

This study does not require research ethics committee approval. It is declared that the study complies with the ethical rules.

\section{REFERENCES}

Abu-Assab, N. (2017). Destabilising Gender Dynamic: Syria post-2011. Jane Freedman et al. (Eds.) in A Gendered Approach to the Syrian Refugee Crisis (pp. 16-25) New York: Routledge.

Aydın, M. et al. (2015). Strateji ve Güvenlik, (5th Ed.), Eskişehir: Açıköğretim Fakültesi Yayınları.

Baldwin, D. (1997). The Concept of Security. Review of International Studies, 23(1), 526.

Beltz, A. (2008). Prosecuting Rape in International Criminal Tribunals: The Need to Balance Victim's Rights with the Due Process Rights of the Accused. Journal of Civil Rights and Economic Development, 23(1), 167-209.

Bilgin, P. (2010). Güvenlik Çalışmalarında Yeni Açılımlar: Yeni Güvenlik Çalışmaları. Stratejik Araştırmalar, 8(14), 69-96.

Blanchard, E. M. (2003). Gender, International Relations, and the Development of Feminist Security Theory. Signs, 28(4), 1289-1312.

Buzan, B. (1991). People, States and Fear: An Agenda for International Security Studies in the Post-Cold War. London: Pearson Longman.

Demirtaş, B. (2019). Feminizm ve Güvenlik. Güvenlik Yazıları Serisi. No:3 https://trguvenlikportali.com/wpcontent/uploads/2019/10/FeminizmGuvenlik_ BirgulDemirtas_v.2.pdf (Date of Access: 10 May 2021). 
EC (2020). European Civil Protection and Humanitarian Aid Operations. European Commission. https:/ec.europa.eu/echo/where/middle-east/syria_en (Date of Access: 17 July 2021).

Enloe, C. (2014). Bananas, Beaches and Bases: Making Feminist Sense of International Politics, University of California Press: Berkeley CA.

Erdoğan, M. (2016). Suriyeliler Barometresi. http://mmuraterdogan.files.wordpress.com (Date of Access: 10 May 2021).

HRC (2016). Human Rights Violations against Women and Girls in Syria. Human Rights $\begin{array}{lllll}\text { Council. } & 24 & \text { March } & 2016 . & \mathrm{https} / / \mathrm{www} . u p r\end{array}$ info.org/sites/default/files/document/syrian_arab_republic/session_26__november_2016/js7_upr26_syr_e_main.pdf (Date of Access: 13 May 2021).

Karakoç Dora, Z. (2020). International Migrants as a Matter of Security: Open Door Policy and Syrians in Turkey. Güvenlik Bilimleri Dergisi, 9(2), 501-524.

Özdemir, Ö. \& Özdemir, E. (2018). Suriyeli Mülteci Kadınlar ve İnsani Güvenlik. Güvenlik Stratejileri, 14(27), 114-145.

Peoples, C. \& Vaughan-Williams, N. (2010). Critical Security Studies. New York: Routledge.

SNHR (2019). 28,076 Females Have Been Killed in Syria since March 2011. 25 November 2019. Syrian Network of Human Rights, https://sn4hr.org/wpcontent/pdf/english/28076_Females_Have_Been_Killed_in_Syria_since_Marc h_2011_en.pdf (Date of Access: 13 May 2021).

Şener, B. (2017). Soğuk Savaş Sonrası Dönemde Uluslararası Göç Olgusu ve Ulusal Güvenlik Üzerindeki Etkileri Üzerine Bir Değerlendirme. Güvenlik Bilimleri Dergisi, 6(1), 1-31.

Terriff, T. et al. (1999) Security Studies Today, Cambridge: Polity Press.

Tickner, J. A. (1997). You Just Don't Understand: Troubled Engagements between Feminists and International Relations Theorists. International Studies Quarterly, 41(4), 611-632.

Tickner, J. A. (2004). Feminist Responses to International Security Studies. Peace Review, 16(1), 43-48.

TIMEP (2017). Syria's Women: Policies and Perspectives. The Tahir Institute for Middle East Policy. Report: 5 September 2017.

Tuzcu, A. \& Ilgaz, A. (2015). Göçün Kadın Ruh Sağlığı Üzerine Etkileri. Psikiyatride Güncel Yaklaşımlar - Current Approaches in Psychiatry. 7(1), 56-67.

Ullman, R. H. (1983). Redefining Security. International Security 8(1), 129-153.

UNFPA (2014). Women and Girls in the Syria Crisis. The United Nations Population Fund. Amman.

UNFPA (2019). Voices from Syria 2019. The United Nations Population Fund. https://www.humanitarianresponse.info/sites/www.humanitarianresponse.info/f iles/documents/files/voices_from_syria_2019_0_0.pdf(Date of Access: 11 May 2021). 
UNHCR (2015). Worldwide Displacement HitsAll-Time High as War and Persecution Increase. Office of the United Nations High Commissioner for Refugees. New York.

UNHCR (2019). Syria Regional Refugee Response - Turkey. http://data.unhcr.org (Date of Access: 29 April 2021).

UN Human Rights Council (2018). "I Losy My Dignity”: Sexual and Gender-Based Violence in the Syrian Arab Republic. https://www.ohchr.org/Documents/HRBodies/HRCouncil/CoISyria/A-HRC37-CRP-3.pdf (Date of Access: 17 July 2021).

UNSC (2000). Security Council Resolution 1325 on Women, Peace and Security. United Nations Security Council, S/RES/1325.

UN Security Council Resolution 1325 (2010). http://www.un.org (Date of Access: 03 May 2021).

UN Women (2021). Global Database on Violence against Women: Syrian Arab Republic.İ https://evaw-global-database.unwomen.org/en/countries/asia/syrianarab-republic (Date of Access: 20 April 2021).

WB (2019). The Mobility of Displaced Syrians. World Bank. https://www.worldbank.org/en/country/syria/publication/the-mobility-ofdisplaced-syrians-an-economic-and-social-analysis (Date of Access: 17 July 2021).

WHO (2019). Undercounting, Overcounting and the Longevity of Flawed Estimates: Statistics on Sexual Violence in Conflict. World Health Organization. https://www.who.int/bulletin/volumes/89/12/11-089888/en/ (Date of Access: 11 May 2021).

WILPF (2016). Violations Against Women in Syria and the Disproportionate Impact of the Conflict on Them. Women's International League for Peace and Freedom. http://wilpf.org/wp-content/uploads/2016/06/WILPF_VAW_HC-2016_WEBONEPAGE.pdf (Date of Access: 17 July 2021).

Wyke, T. (2015), Turkey Launches Deadly Airstrikes on ISIS and PKK bases as Kurds Threaten to Tear up Ceasefire Agreement. 25 July 2015. Daily Mail, www.dailymail.co.uk/news/article-3174295/Fighting-Turkey-launches-deadlyairstrikes-ISIS-PKK-bases-Kurds-threaten-tear-ceasefire-agreement.html (Date of Access: 14 May 2021).

Wyn-Jones, R. (1996), Travel without Maps: Thinking about the Security after the Cold War. Jane Davis (Ed.) in Security Issues in the Post-Cold War World, (PP. 196218). M. Cheltenham: Edward Elgar. 